\title{
Experimental Studies on Acute and Direct Effects of Insulin on the Regulaton of Hepatic Metabolism
}

\section{Masayoshi YOSHIDA}

The Third Department of Internal Medicine, Nagoya University, School of Medicine, Nagoya, Japan. (Director : Professor Kozo Yamada) :

III Defect of Insulin Action on the Hepatic Enzymes in Obese Hyperglycemic Mice.

Previous findings in our laboratory suggest that insulin exerts its effect on the hepatic metabolism through the rapid alteration of some enzyme activities and afford some evidences to believe that the primary site of insulin action would be a "channeling" of metabolic flux, presumably during glucokinase or pyruvate kinase reaction. If the mechanism of "channeling" is impaired in some way, the direct effect of insulin on the hepatic metabolism should be abolished and this would result in the decrease of glucose tolerance in spite of the presence of insulin in excess. Thus, diabetes with hyperinsulinemia might develop.

To clarify this hypothesis, the direct effect of insulin on the hepatic metabolism in genetically obese hyperglycemic mice was studied, since these animals show several clinical features resembling to those seen in human obese adult-onset diabetics with hyperinsulinemia.

Obese hyperglycemic Bar-Harbor mice (C57BL/6J-ob) originally derived from the Jackson Laboratory at age of 4-5 months old and also 7-9 months old were used. Total evisceration except the liver was performed by the technique previously reported. Glucose $(550 \mathrm{mg} / \mathrm{kg} / \mathrm{hr}$.) or glucose with insulin $(1.5$ or $3.0 \mathrm{u} / \mathrm{kg} / \mathrm{hr}$.) was infused through portal catheterisation for 20 minutes and the activities of key glycolytic and gluconeogenic enzymes were measured. The results obtained were as follows:

1. The activities of key glycolytic and gluconeogenic enzymes in the young obese mice were several fold higher than those of lean litter mates.

2. In the lean mice, the activities of key glycolytic enzymes were significantly elevated by the administration of insulin, whereas the activities of key gluconeogenic enzymes were not influenced by the hormone.

3. In the obese mice no significant effects of insulin on the enzyme activities were observed.

4. From analysis of the ratio of key glycolytic enzyme activity to the corresponding key gluconeogenic enzyme activity, it might be concluded that insulin exerts its direct effect on a channeling of metabolic flux between glucose and glucose-6-phosphate.

From these results, a possible mechanism of development of diabetes with hyperinsulinemia was discussed in some detail. (Original is written in Japanese.)

(See pp. 659〜669) 


\section{肝におけるインスリン効果とくに早期効果に}

\section{関する実験的研究（第 3 報）}

一一肥満・高血糖マウスの肝酵素に対するインスリン効果の不全について—

名古屋大学医学部内科学第 3 講座（指導 山田弘三教授）

吉田正義

(昭和47年 8 月 9 日受付)

人の過インスリン（以下「イ」と略）血症を伴う糖尿病の成因追求の為に臨床像がよく似た先天的肥 満・高血糖マウス (C57BL/6J-ob) を選び内臓全剔肝残存標本を作成し，グルコース $(550 \mathrm{mg} / \mathrm{kg} / \mathrm{hr})$

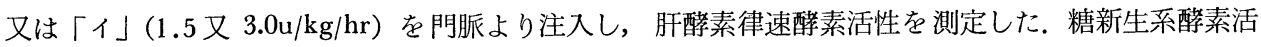
性/解糖系醉素活性比の分析から「イ」は glucose と glucose-6-phosphate の間の代謝の方向 “転換” に直接効果を及ぼすものと推論される。肥満・高血糖マウスではその「イ」効果が非肥満健常マウスに 比して極めて減弱しており，てれが糖尿病状態の発症に重大な意義をもつと思われる.

\section{I 緒 言}

糖尿病の発症には in vivo におけるインスリン（以下「イ」と略す）効果の不足が決定的な要因である ことは今日疑いないとてろである。 ての「イ」効果の不足が膵 $\beta$ 細胞の不全に基く「イ」生成ないし分必障 害による所謂 Insulinmangeldiabetes については原理的には問題なく理解される。しかしながら「ヒト」糖 疗病の $80 \%$ 以上を占める eu〜hyperinsulinemia を伴う糖尿病の成立機序に就いては今日尚一致した見解は 得られていない. Hyperinsulinemia を伴いながら尚且つ糖尿病を発症する事実は, 存在する「イ」が生物 学的作用を有しない異常「イ」でない限り何らかの「イ」阻害が存在すると考えざるを得ない.「イ」効果 の阻害に関して従来多くの仮説が提唱されているが，その多くは「イ」の存在様式の異常を以つて説明せん とするもので「イ」が直接非活性化されることを前提としたものである.しかしながらてれらの諸説は今日 に至るも尚広く受け入れられるに足る根拠に乏しく， hyperinsulinemia を伴う糖尿病の原因としては決定 的な説明となり得ない。「イ」は膵島より分泌された後, 肝を経て大偱環系に入り種々の標的組織に至つて 「イ」効果を発掸するが，肝をはじめとするてれら種々の「イ」依存組織に於いて，「イ」が作用を発揮す べきメカニズム（「イ」依存機構）に異常が存在する場合には「イ」の側に異常が全くないとしても「イ」 効果は発現しないであろうし，てれは当然糖尿病を招来し得ると考えられる. 当研究室では数年来, 経口摄 取されたグルコースが最初に到達する肝代謝に及ぼす「イ」効果特に早期効果に就いて研究し，既に「イ」 が門脈内に大量投与された場合のみきわめて早期に解糖系 key enzyme 活性が上昇し, 又一部の糖新生系 key enzyme 活性が抑制されるととを報告した ${ }^{122) 3(4)}$. この肝に於ける「イ」依存機構特に早期に作動する メカニズムに障害が存在すれば, 少なくとも耐糖能は強く障害され糖尿病状態が誘発され, しかも hyperinsulinemia が併存しうるとととなりと卜成人型糖尿病発症の原因解明に鐩を提供するものと考える. 著者は ヒト成人型糖尿病のモデルとして先天的肥満・高血糖マウスを選びその肝「イ」依存機構と「イ」の関連を 追求した. その成績を以下に示すと共に上述の問題を中心として種々考察を加えた. 


\section{II 実 験 方 法}

1 ) 実験動物 : Bar Harbor obese hyperglycemic mouse (G57BL/6J-ob) の 5 対を Jackson Memorial Laboratory より購入し, メタボリックケージ中でオリエンタル固形食にて飼育, 交配・繁殖させ, 月令 4 〜 月及び 7〜8 ケ月の雄性肥満マウス(以下肥満マウス)を実験に供した。対照には同腹の雄性非肥満マウ ス(以下非肥満マウス)を用いた，実験は以下に示す各群に就いて行なつた。

i ）絶食断頭群：18時間絶食後断頭屠殺したもの.

ii）飽食断頭群：18時間絶食後 3 時間に亘りオリエンタル固形食を ad libitum に与え断頭屠殺したもの. iii）グルコース単独投与群：18時間絶食後麻酔下に実験方法に示す内藏全剔肝残存標本となし閒脈に設置 したカテーテルを通じ $550 \mathrm{mg} / \mathrm{kg} / \mathrm{hr}$ のグルコースを持続注入器を用いて注入した.

iv）「イ」投与群：iii）と同様に処置したマウスに同様門脈カテーテルよりグルコースを注入，20分後よ り側路カテーテルを介して「イ」を門脈内に注入した. 注入「イ」量により $1.5 \mathrm{u} / \mathrm{kg} / \mathrm{hr}$ の少量群と $3.0 \mathrm{u} / \mathrm{kg} /$ $\mathrm{hr}$ の大量群に区別した。前者は頸静脈より注入した場合末梢血糖値の低下を認めるが，門脈内に投与した 場合には末梢血糖值に影響を認めない最大值であり, 後者は門脈内に投与して確実に未梢血糖值の低下を認 める最小值である ${ }^{3)}$.

2 ）実験方法 ${ }^{3)}$ : 実験マウスを nembutal 麻酔下に開腹, 以下当研究室に於て開発した術式に基づいて内 藏全剔肝残存標本を作成，門脈内に挿入したカテーテルよりグルコース，或いは「イ」十グルコースを注入， 注入前より40分間に亘り10分毎に尾静脈より採血，血糖值を測定すると共に注入終了後直ちに肝葉を採取し， 諸種肝酵素活性 (hexokinase, EC 2.7.1.1. (HK). glucokinase, EG 2.7.1.2 (GK). phosphofructokinase, EC 2.7.1.11 (PFK), pyruvatekinase, EC 2.7.1.40 (PK). glucose-6-phosphate dehydrogenase, EC 1.1.1. 49 (G6P-DH). glucose-6-phosphatase, EC 3.1.3.9 (G6 Pase). fructose-1, 6-diphosphatase, EC 3.1.3.11 (FDPase). phosphoenolpyruvate carboxykinase, EC 4.1.1. 32 (PEP-CK)). を測定した. 尚切除肝切片は 速かに氷冷中にホモゲナイズし 100,000G，60分間遠心，上清を肝酵素活性測定に用いた. G6Pase, FDPase 活性測定には homogenate を用いた。 酵素活性は肝湿重量当りで算出した.

\section{3 ）測定方法}

Glucose : Glucose-Oridase 法

HK 2.7.1.1 : Vinuela 法 $^{5)}$

GK 2.7.1.2 : Vinuela 法 $^{5)}$

PFK 2.7.1. 11 : Underwood 法 ${ }^{6)}$

PK 2.7.1 40 : Bücher 法7)

G6Pase 3.1.3.9: Harper 法 $^{8)}$

FDPase 3.1.3.11 : Backer 法9)

PEP-CK 4.1.1.32 : Ballard 法 ${ }^{10)}$

G6P-DH 1.1.1.49 : Löhr 法 ${ }^{11)}$

試薬:「イ」は清水製薬の glucagon free insulin. 酵素活性測定用酵素標品, nucleotide ・基質標品は Boehringer Mannheim 社, 一部は Sigma 社製品を用いた。

\section{III 実 験 成 績}

Table 1. A) は断頭屠殺後の肥満及び非肥満マウス肝酵素活性を示したものである. 糖新生系, 解糖系 を問わず key enzyme 活性は何れも肥満マウスで強く妄進している. 肥満マウスでは老令化と共に key glycolytic enzyme 活性は㠵進し, key gluconeogenic enzyme 活性は一般に低下傾向を示す (Fig. 1). 従つて gluconeogenic activity/glycolytic activity 比は月令の進行と共に低下を示し, 糖尿病では老令化 
Table 1. Hepatic enzyme activities of obese hyperglycemic Bar-Harbour mice and their lean littermates under various experimental conditions

\begin{tabular}{|c|c|c|c|c|c|c|c|c|c|}
\hline $\begin{array}{l}\text { experimental } \\
\text { condition }\end{array}$ & animal & $\begin{array}{l}\text { glucose- } \\
6- \\
\text { phosph- } \\
\text { atase }\end{array}$ & \begin{tabular}{|l|} 
fructose \\
$1-6-$ \\
dipho \\
sphatase
\end{tabular} & \begin{tabular}{|l|} 
phosp- \\
hoenol \\
pyruvat- \\
e \\
carboxy- \\
kinase
\end{tabular} & $\begin{array}{l}\text { hexokin- } \\
\text { ase }\end{array}$ & $\begin{array}{l}\text { glucoki- } \\
\text { nase }\end{array}$ & $\begin{array}{l}\text { phospho- } \\
\text { fructokinase }\end{array}$ & \begin{tabular}{|l|} 
glucose- \\
6- \\
phosph- \\
ate \\
dehydro- \\
genase
\end{tabular} & \begin{tabular}{|l} 
pyruvat- \\
ekinase
\end{tabular} \\
\hline \multirow{2}{*}{$\begin{array}{l}\text { A) } \\
\text { 18hrs. fasted }\end{array}$} & $\mathrm{C}^{*}$ & $\begin{array}{l}19.9 \\
\pm 1.6\end{array}$ & $\begin{array}{l}15.8 \\
\pm 2.8\end{array}$ & \begin{tabular}{|l|}
7.77 \\
\pm 6.4
\end{tabular} & $\begin{array}{l}188.4 \\
\pm 17.2\end{array}$ & & & \begin{tabular}{|l|}
116 \\
\pm 17
\end{tabular} & \\
\hline & $\mathrm{O}^{*}$ & $\begin{array}{l}32.7 \\
\pm 1.9\end{array}$ & & $\begin{array}{l}22.8 \\
\pm 3.2\end{array}$ & $\begin{array}{l}598.2 \\
\pm 64.2\end{array}$ & & & & \\
\hline \multirow{2}{*}{$\begin{array}{l}\text { B) } \\
\text { glucose infused } \\
(550 \mathrm{mg} / \mathrm{kg} / \mathrm{hr} .)\end{array}$} & C & $\begin{array}{l}20.9 \\
\pm 1.4\end{array}$ & $\begin{array}{l}17.6 \\
\pm 1.5\end{array}$ & $\begin{array}{l}7.6 \\
\pm 1.9\end{array}$ & $\begin{array}{l}166.1 \\
\pm 29.6\end{array}$ & $\begin{array}{l}142.4 \\
\pm 13.4\end{array}$ & $\begin{array}{l}28.8 \\
\pm 2.6\end{array}$ & $\begin{array}{l}125 \\
\pm 25\end{array}$ & $\begin{array}{l}720.2 \\
\pm 32.7\end{array}$ \\
\hline & $\mathrm{O}$ & $\begin{array}{l}28.8 \\
\pm 1.7\end{array}$ & $\begin{array}{l}29.7 \\
\pm 2.6\end{array}$ & $\begin{array}{l}6.9 \\
\pm 2.8\end{array}$ & $\begin{array}{l}323.8 \\
\pm 25.8\end{array}$ & $\begin{array}{l}392.2 \\
\pm 19.0\end{array}$ & & $\begin{array}{l}162 \\
\pm 28\end{array}$ & $\begin{array}{l}2290.0 \\
\pm 102.1\end{array}$ \\
\hline \multirow{2}{*}{$\begin{array}{l}\text { C) } \\
+ \text { insulin infused } \\
\text { (1.5units } / \mathrm{kg} / \mathrm{hr} .)\end{array}$} & G & $\begin{array}{l}26.7 \\
\pm 1.5\end{array}$ & $\begin{array}{l}17.3 \\
\pm 1.1 \\
\end{array}$ & $\begin{array}{l}7.3 \\
\pm 4.2\end{array}$ & $\begin{array}{l}156.4 \\
\pm 53.6\end{array}$ & $\begin{array}{l}164.2 \\
\pm 14.0\end{array}$ & $\begin{array}{l}46.0 \\
\pm 5.1 \\
\end{array}$ & $\begin{array}{l}154 \\
\pm 12\end{array}$ & $\begin{array}{l}857.4 \\
\pm 42.8 \\
\end{array}$ \\
\hline & $\mathrm{O}$ & $\begin{array}{l}28.7 \\
\pm 2.9\end{array}$ & $\begin{array}{l}29.6 \\
\pm 2.1\end{array}$ & $\begin{array}{l}7.1 \\
\pm 3.2\end{array}$ & $\begin{array}{l}400.4 \\
\pm 76.2\end{array}$ & $\begin{array}{l}234.2 \\
\pm 11.0\end{array}$ & & $\begin{array}{l}182 \\
\pm 34\end{array}$ & $\begin{array}{l}1859.4 \\
\pm 121.0\end{array}$ \\
\hline \multirow{2}{*}{$\begin{array}{l}\text { D) } \\
+ \text { insulin infused } \\
\text { (3.0units } / \mathrm{kg} / \mathrm{hr} .)\end{array}$} & $\mathbf{G}$ & $\begin{array}{l}22.5 \\
\pm 1.8\end{array}$ & $\begin{array}{l}16.0 \\
\pm 1.7\end{array}$ & $\begin{array}{l}11.3 \\
\pm 2.5\end{array}$ & $\begin{array}{l}283.2 \\
\pm 61.0\end{array}$ & $\begin{array}{l}376.8 \\
\pm 34.8 \\
\end{array}$ & $\begin{array}{l}57.8 \\
\pm 6.7\end{array}$ & $\begin{array}{l}228 \\
\pm 35\end{array}$ & $\begin{array}{r}1301.4 \\
\pm 32.8 \\
\end{array}$ \\
\hline & $\mathrm{O}$ & $\begin{array}{l}32.5 \\
\pm 1.5\end{array}$ & $\begin{array}{l}26.3 \\
\pm 1.4\end{array}$ & $\begin{array}{l}11.1 \\
\pm 4.8\end{array}$ & $\begin{array}{l}454.4 \\
\pm 58.8\end{array}$ & $\begin{array}{l}386.2 \\
\pm 8.2\end{array}$ & $\begin{array}{l}154.0 \\
\pm 7.2 \\
\end{array}$ & $\begin{array}{l}274 \\
\pm 47\end{array}$ & $\begin{array}{l}2577.6 \\
\pm 132.7 \\
\end{array}$ \\
\hline \multirow{2}{*}{$\begin{array}{l}\text { E) } \\
\text { refed after } \\
\text { 18hrs. fast }\end{array}$} & $\mathrm{G}$ & $\begin{array}{l}19.4 \\
\pm 2.7\end{array}$ & $\begin{array}{l}15.8 \\
\pm 1.8\end{array}$ & $\begin{array}{l}6.2 \\
\pm 1.1\end{array}$ & $\begin{array}{l}240.0 \\
\pm 17.8\end{array}$ & $\begin{array}{l}162.0 \\
\pm 7.1 \\
\end{array}$ & $\begin{array}{l}86.0 \\
\pm 5.8\end{array}$ & $\begin{array}{l}90 \\
\pm 5\end{array}$ & $\begin{array}{l}808.7 \\
\pm 41.3 \\
\end{array}$ \\
\hline & $\mathrm{O}$ & $\begin{array}{l}29.4 \\
\pm 3.2\end{array}$ & $\begin{array}{l}27.7 \\
\pm 2.1\end{array}$ & $\begin{array}{l}16.1 \\
\pm 3.7 \\
\end{array}$ & $\begin{array}{l}244.9 \\
\pm 11.2 \\
\end{array}$ & $\begin{array}{l}543.6 \\
\pm 13.7 \\
\end{array}$ & $\begin{array}{l}179.4 \\
\pm 7.1 \\
\end{array}$ & $\begin{array}{l}210 \\
\pm 12\end{array}$ & $\begin{array}{l}3005.0 \\
\pm 107.8 \\
\end{array}$ \\
\hline
\end{tabular}

activities are expressed as $\mu$ moles substrate converted/g wet liver/min.

${ }^{*} \mathrm{C}:$ non-obese non-hyperglycemic mice

$\mathrm{O}$ : obese hyperglycemic littermates

Fig. 1. Ghanges of hepatic enzyme activities of Bar-Harbour obese mice by aging

$\square$ old obese mice
young obese mice

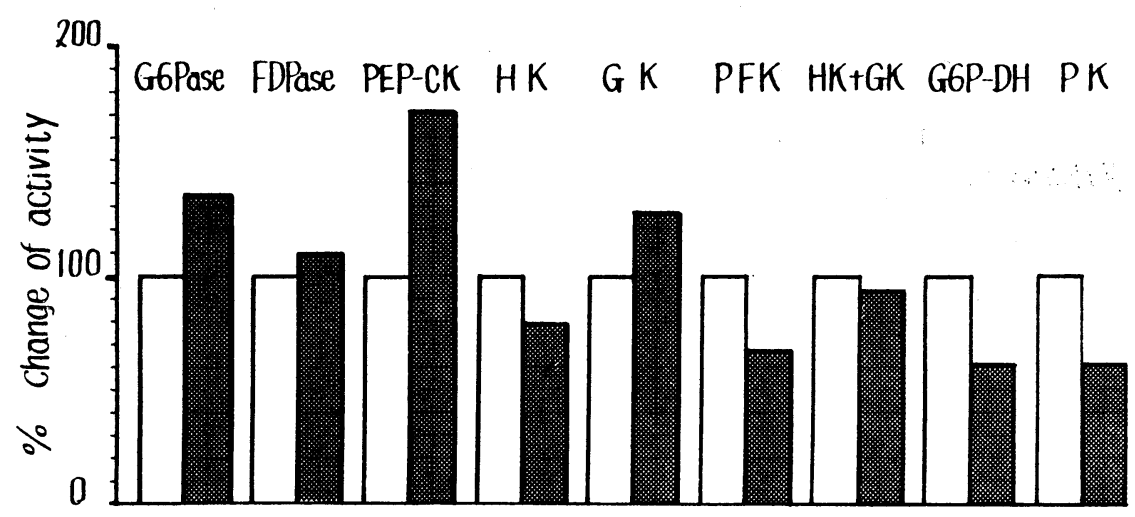

と共に肥満, 高血糖とも正常化する現象 ${ }^{12)}$ よく一致する.

Fig. 2 は内臓全剔肝残存標本に門脈内よりグルコースを40分間に亘り注入した後の肝酵素活性を $100 \%$ と し，乙れに対しグルコース注入開始20分後より20分に亘り「イ」を注入した後の肝酵素活性の変化を「百分 比で」示したものである. 非肥満マウスの解糖系酵素活性は「イ」少量投与時には変化を認めないが，大量 
Fig. 2. Acute effect of insulin on glycolytic enzyme activities in the liver from $18 \mathrm{hrs}$. starved non-obese littermates

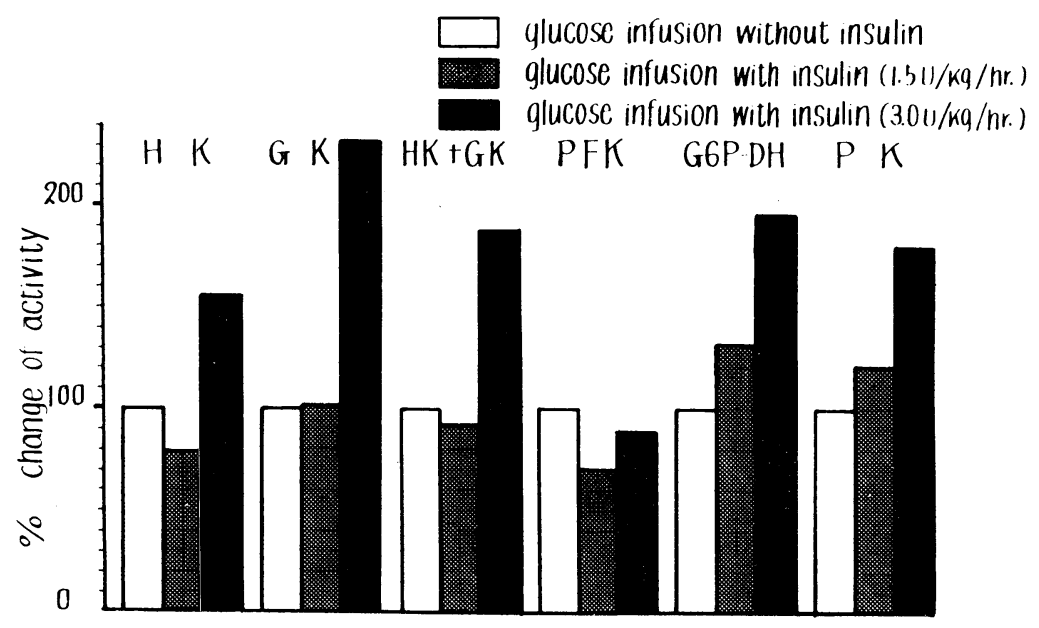

Fig. 3. Acute effect of insulin on glycolytic enzyme activities in the liver from $18 \mathrm{hrs}$ starved obese mice

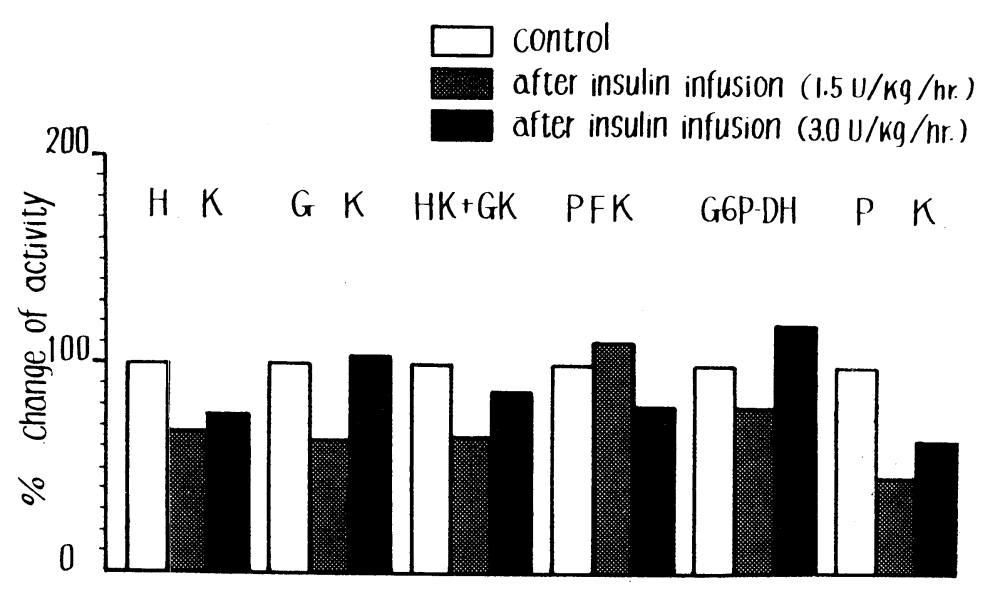

投与時にはPFK を除き何れも顕著な活性上昇を来し，「イ」の早期効果を明らか認めうる。 又との活性 は全て断頭屠殺時の肝醉素活性を遙が上迴つている。乙れに反して肥満マウスでは「イ」の少量, 大量を 問わず活性変化は殆んど認められず，僅かに G6P-DH 活性が大量投与で上昇するにすぎないが，乙の活性 は断頭屠殺時の活性とほぼ同じレベルにあり有意とはいえない. (Fig. 3) 一方糖新生系酥素活性は肥満, 非 肥満を問わず「イ」投与により G6Pace, PEP-GK 活性に多少の增加をみる他は概㸚著変を認めない. (Table 1C)，D)）乙の両群における「イ」効果の差は Fig. 4 亿最も明瞭にみるてとが出来る．Fig. 4 は $3.0 \mathrm{u} / \mathrm{kg} / \mathrm{hr}$ の「イ」投与後の酵素活性をグルコース単独投与時の醳素活性と比較したものである. 肥満マウ スでは非肥満マウスに比し G6P-DH を除いて「イ」反応性が極めて不良である. 肥満マウスを空腹時血糖 の $149 \mathrm{mg} \%$ 以下を示す比較的軽症糖尿病群と $150 \mathrm{mg} \%$ 以上を示す重症糖尿病群に 2 大別してそれぞれの肝解 糖系酵素活性及びそれに及ぼす「イ」効果を比較検討したものが Fig. 5 である． 糖尿病状態が比較的軽症 にとどまる群では「イ」に対する活性の反応は正常に保持されているのに反し，重症糖尿病群では明らかに 
Fig. 4. Acute effect of a large dose insulin administered into portal circulation on the glycolytic enzyme activities in the liver from obese and lean mice

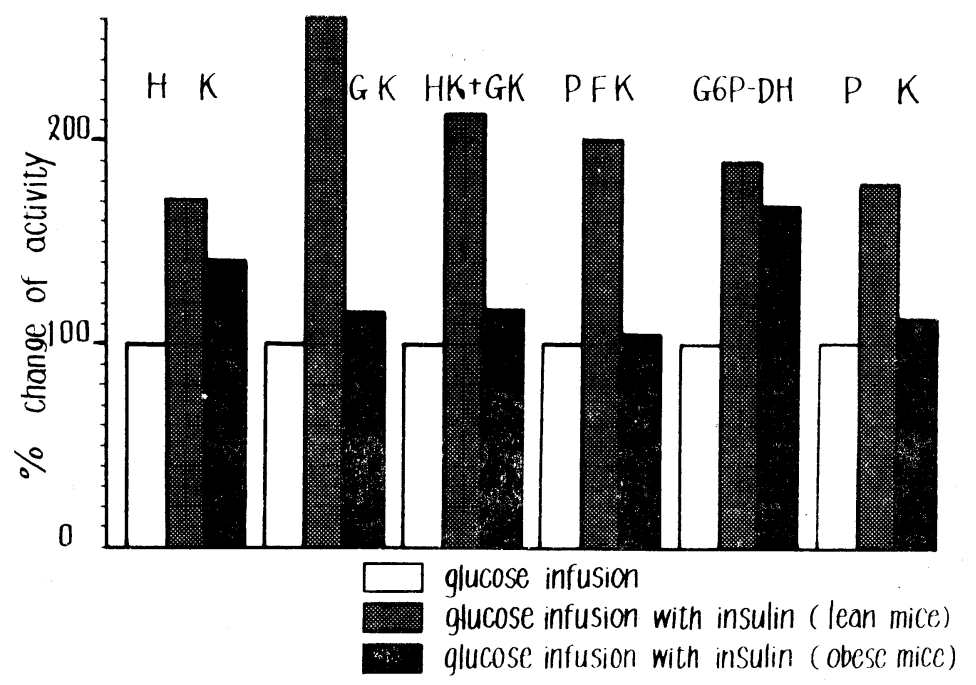

Fig. 5. Acute effect of insulin on glycolytic enzyme activities in the liver from Bar-Harbour obese mice

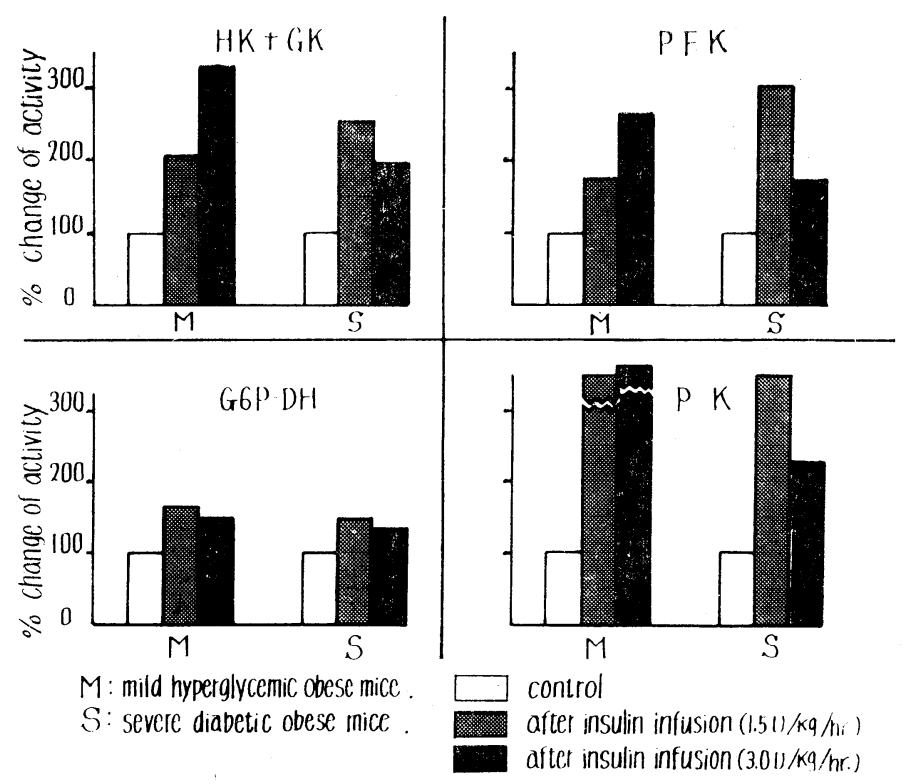

反応性の低下を認めうる。Fig. 6 は「イ」3.0u/ $\mathrm{kg} / \mathrm{kr}$ を投与した場合の軽症糖尿病群の酵素活性に対する 重症糖尿病群の酵素活性百分比を示したものである。何れの群も肥満の程度に差異は認められないにも拘ら ず肝解糖系酵素の「イ」に対する早期反応性に差のみられる事実は本系マウスにみられる肥満要因と糖尿病 要因は相互に影響を与え合う可能性を否定できないが，本質的には別個のものであることを示陖している。 
Fig. 6. Acute effect of insulin on the enzyme activities in the liver from mild hyperglycemic obese mice and severe diabetic obese mice

$\square$ mild hyperglycemic obese mice

severe diabetic obese mice

G6Pase FDPase PEP-CK HK GK PFK HKrGK G6PDH P K

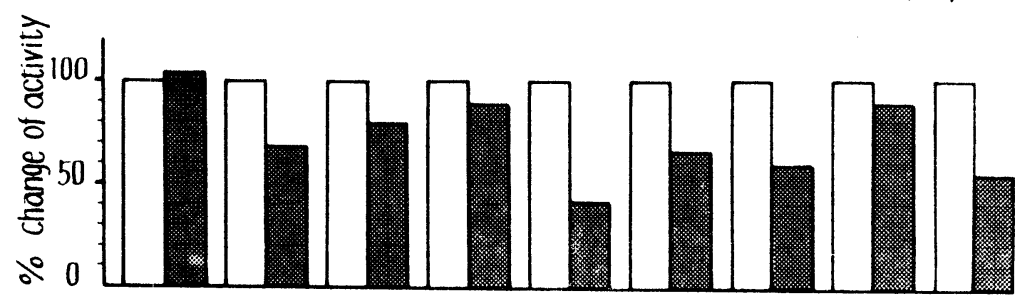

Fig. 7. Ratio of enzyme activity of lean mice corresponding to enzyme activity of obese littermates

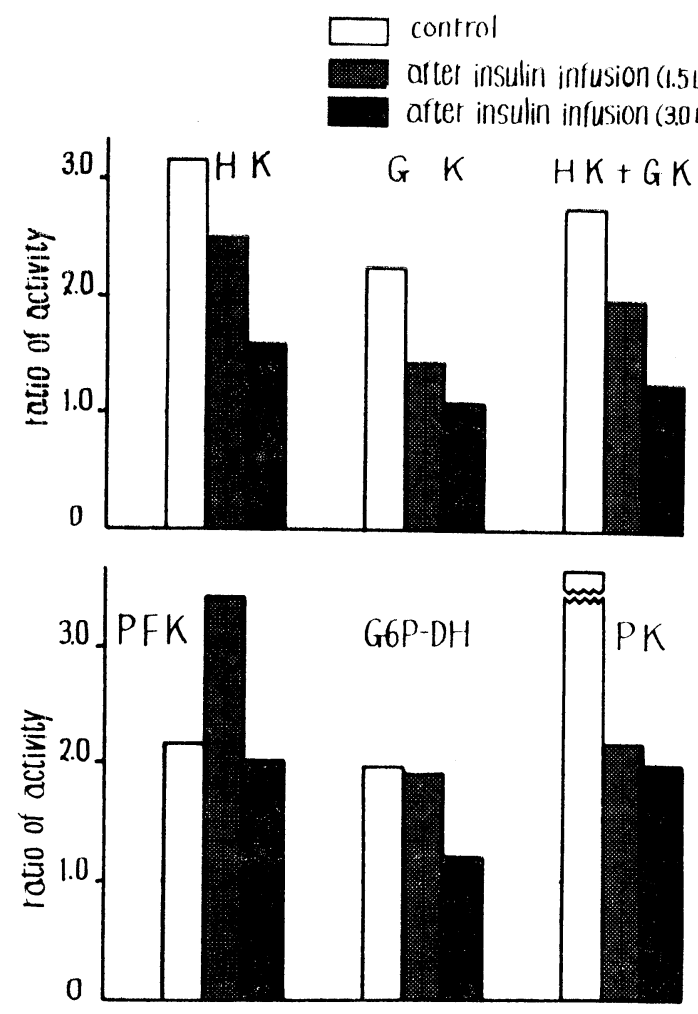

Fig. 7 は断頭屠殺後, 「イ」 $1.5 \mathrm{u} / \mathrm{kg} / \mathrm{hr}$ 投与後, 及び「イ」3.0u/kg/hr 投与後の各醉素活性を肥満/ 非肥満 比で示したものである. 既述の如く断頭屡殺後の活性比は肥満群で何れも $2 \sim 3$ 倍の高值を示しているが, 「イ」投与後活性比は何れる断頭屠殺時に比して低下を示し, 肥満群解糖系醉素活性の「イ」に対する反応 
Fig. 8. Effect of insulin on the ratio of gluconeogenic enzyme activity corresponding to glycolytic enzyme activity

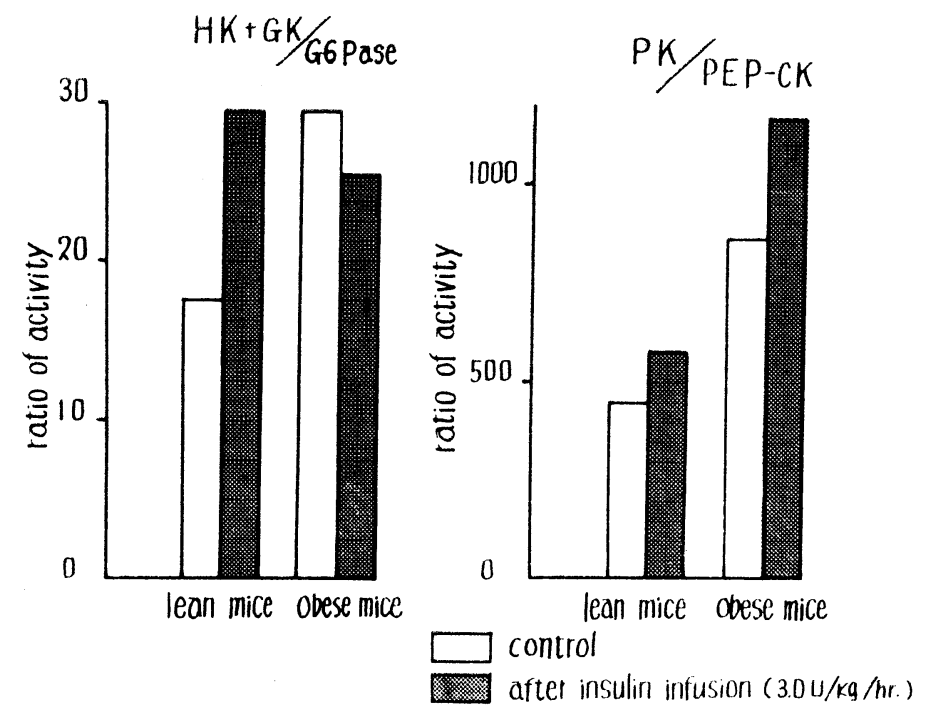

性ないしは感受性の低下していることがうかがわれる．Fig. 8 は HK, GK 及び PK 反応とそれぞれ逆方 向の反応を触媒する G6Pase, PEP-CK 反応の活性比を断頭屠殺時及び「イ」投与後について示したもので ある，肥満マウスではどのステップでも有意の変化を認めないが，非肥満マウスでは $\frac{\mathrm{HK}+\mathrm{GK}}{\mathrm{G} 6 \mathrm{Pase}}$ 比が「イ」 投与によつて有意の増加を示す。この成績は肝酵素活性に及ぽす「イ」早期効果がこのステップで発揮され るととを意味するものとして興味深い.

\section{IV 考察}

血糖の homeostasis 維持に於ける肝の決定的役割について今さら云々するまでもない，糖尿病に際して は「イ」不足に基いて末梢組織に於けるグルコース利用は著しく低下するがその代償性反応として細胞外糖 濃度即ち血糖の増加を来たすととは Soskin らの膵摘糖尿病犬の実験により明確に示されている．ての糖尿 病にみられる高血糖は主として肝に於ける糖新生元進によつて維持されている. 尚ての肝糖新生の元進は朋 key gluconeogenic enzyme 活性の亢進, key glycolytic enzyme 活性の低下によつてもたらされるてとが 実験的にも臨床的にも実証されている. Key glycolytic enzyme の誘導が「イ」によつて支配されており ${ }^{13)}$ 14)15)糖尿病に際して, その生合成が著しく低下するてとは周知の事実であるが，七ト成人型糖尿病に於ては しばしば血中「イ」量は正常乃至過剩に存在し膵よりの分泌もしばしば過剩反応型を呈するてとが知られて いる ${ }^{16) 17)}$. 正常乃至過剩の「イ」存在下に発症する糖尿病の本態は当然「イ」久乏型のそれとは異る筈であ り広義の「イ」抵抗性を以つて説明されうるものである。この「イ」抵抗性は従来 free〜 bound insulin 説 $(\text { Antoniades } ら)^{18)}$, suppressible $\sim$ nonsuppressible insulin 説 $\left(\right.$ Froesch) ${ }^{19)}$, typical $\sim$ atypical insulin 説 (Samaan ら $)^{20)}$ ，あるいは synalbumin 説 (Vallance-Owen) ${ }^{21)}$ に代表される如く血中蛋白乃至はそれに類似 の inhibitor によつて血中「イ」の存在様式が何らかの修飾をうけ生物学的作用の低減を来たすとして説明 されてきた. そのような可能性は無論完全に否定は出来ないが現在のとてろ hyperinsulinemia を伴う糖尿 病に普遍的にみられる現象とは認め難い，又 immunoassay では「イ」として測定されるが生物学的効果 の極めて微弱であるとされる proinsulin 2223)24)25)26) が hyperinsulinemia を伴う糖尿病患者には多く, 従つ て本態的には「イ」欠乏であるとする考えも魅力的ではあるが実証性にそしい. 一方「イ」の標的組織におけ る糖利用が阻害された場合には糖尿病状態は当然招来される筈であり，同時に反応性 hypesinsulinemia を 
伴うべきととも容易に理解されうる ${ }^{4)}$. 上述の血中「イ」の存在様式の異常による糖尿病も広義にはての範 疇で理解できるが，仮にてれら humoral inhibitor を以つて説明し得ないとするならば，「イ」の target organ における「イ」利用機構自体の異常による「イ」効果の不足が考慮されてよい，グルコースを利用す る上で量的にも質的にも最も「イ」に依存する組織としては筋及び脂肪組織が挙げられ実際糖尿病に際して てれら組織の「イ」感受性が低下しているとする報告も少なくない27282). 併しながら hyperinsulinemia を 伴う糖尿病では筋・脂肪組織は一般に発育良好であり，乙れらの「イ」感受性低下，グルコース利用障害が 糖尿病の一義的成因であるとは考光難い，既報の如く正常ラットの内臓剔出肝残存標本を用いた成績から或 る特定の肝酵素活性が大量の「イ」によつて極めて早期に变動することは確実である。もしての大量の「イ」 投与によつても肝酵素活性調節機構が作動しないとすれば，肝にわける糖利用は強く障害され耐糖能は低下 し，グルコースの利用は大幅に筋・脂肪組織を中心とする末梢組織に依存せざるを得ず29)，その結果は高血 糖 $\rightarrow\lceil 1 」$ 追加分泌の過剩 $\rightarrow$ 筋・脂肪組織の增大を齊らし，ヒ卜成人型糖尿病の病像と一致する代謝論名が 形成される可能性がある. 従つて hyperinsulinemia 肥満を伴う糖尿病について肝醣素活性の「イ」に対す る反応性を検索することは糖尿病の病因解明に極めて重要である。著者は上述の研究目的に基づいて高血糖, 高「イ」血症を有し血管障害，皮膚感染症の合併を来たし易い等の点からヒト成人型糖尿病のモデルとして Bar Harbor mice (C57BL/6Job) を選び実験に供した。実験結果本系マウスの肝 key gluconeogenic enzyme のみならず，key glycolytic enzyme 何れも同腹の非肥満マウスに比して強く元進しているととは Seidman $\zeta^{30}$ ), Willms $ら^{31)}$ の報告と一致する. Key glycolytic enzyme 特に GK 活性の六進は hyperinsulinemia を伴う糖尿病には普遍的にみられるもので22, 例えば New Zealand obese mice ${ }^{3334)}$, Spiny mice ${ }^{31322)}$ ，さらには上卜成人型糖尿病 ${ }^{35)}$ においても観察されている，肥満マウスにおける hyperinsulinism, hyperglycemia など多くの糖尿病性代謝パターンは発生・発育過程に於て大きい変動を示し生後 $2 \sim 4$ ケ 月で最も顕著となるとされているが36377)，肝の酥素パターンも同様である。乙れは hyperinsulinemiaの 消長と平行しているから，いづれかの組織における「イ」抵抗性の存在を意味している ${ }^{34) 38)}$. ての点からみ て内臟全剔肝残存特殊標本を用いる「イ」灌流実験に於ける成績は極めて興味深い，非肥满マウスに $1.5 \mathrm{u} /$ $\mathrm{kg} / \mathrm{hr}$ の「イ」を門脈内に投与しても未梢血糖值は変動せず，肝醉素活性もグルコース単独投与時と比較し て有意の変動を示さない．しかるに $3.0 \mathrm{u} / \mathrm{kg} / \mathrm{hr}$ の「イ」を経門脈的に持続注入する時は末梢血糖值は急速 に低下を示すが，それに応して肝解糖系酵素活性も又急速に充進する，肥満マウスに於ては門脈内に大量の 「イ」を投与しても非肥满マウスにみられる解糖系醉素活性の変化はグルコース単独投与時に比較して殆ん ぞ有意ではない，即ち明らかに肝解糖系醰素の「イ」感受性低下か認められるのである．ての際末梢血糖值 は対照非肥満マウスにみられると同様低下を来たすととから「イ」と同時に注入されたグルコースの処理は 肝ではほとんど行わ机ず，主として末梢に依存しているものと思われる．教室の馬場皇 は $50 \mathrm{~g}$ グルコース 負荷後の血中諸メタボライトの変動パターンの分析から糖尿病に際しては経口的に掑取されたグルコースの 肝による処理能が低下し未梢諸組織によるグルコース処理への依存度が高まると結諭しているが，肥満マウ スは明らかにその成績を裏書きする肝酵素活性パターンを示している，末梢組織特に脂肪組織におけるグル コース利用比率の増大は高い末梢血中「イ」レベルと相俟つて中性脂肪生成の増大を意味し，必然的に肥満 を招来する筈であり，肥満マウスにおける hyperglycemia, hyperinsulinemia, obesity が無理なく理解し 得るのである。肝醳素のてのような「イ」感受性は従来 glycogen synthase に就いて認められている ${ }^{39)}$ 他は 今日尚知られているとてろは少ない，Vester は in vitro 亿於ける GK 活性が「イ」添加により急速に六進

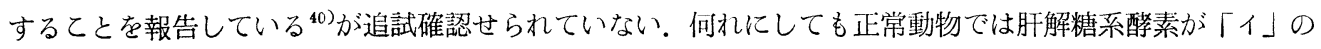
大量投与によつて急速な活性元進を来たすてとは著者の成績より明らかであり, その反応性の喪失が hyperinsulinemia を伴う糖尿病と深い関連を有することは容易に想像される．ラットを用いた野村の成績では ての肝酵素に及ぽす「イ」の早期効果は PEP-CK〜PK の channeling を primary site とするととを示し ているが，マウスにおいては「イ」の作用点はやや異つている.

GK，G6P-DH，PK 何れの key step も明らかな反応を示している。乙てれらの酥素活性は全て in vitro 
に於て至適条件下に該酵素反応のVmax を測定することにより観察されている為, 種々の Co factor 或い は allosteric effector に代表されるような修飾因子の変動を介して活性か湾化するとは考元難い. 即ち醉素 蛋白の変化に基づく活性変化でなければならないが, 酵素蛋白量の増加は時間的経過より考えて先づ起り得 ないと思われる，恐らく䣼素蛋白の構造変化特に subunit の組み変えが大量の「イ」によつて齋らされる ものと想定される。この subunit 組み変えに「イ」もしくはその一部が直接関与するか又は何らかの effector の変化を介して行なれるか尚全く不明と言わざるをえない. 生後 4 ～5 ケ月の肥満マウスと非肥満マウスに おけるそれぞれ対応する䣼素活性比の変動は (Fig. 7) 極めて興味深い. 大量「イ」投与後の肥満 / 非肥満比 が断頭屠殺時の肥満 / 非肥満比に比して HK, GK, PK に於いても低下することは肥満マウスにおける各 key enzyme の「イ」感受性換言すれば「イ」反応性の低下を意味しており，上述の成績を一層明確に示す ものである. この際「イ」による key glycolytic enzyme 活性上昇効果に比して key gluconeogenic enzyme に対する抑制効果は明瞭ではなく，「イ」効果の primary の作用点は key glycolytic enzyme 活性 変化にあるととがよく理解される，扔，てのような「イ」効果が実際上どのように代謝の flux を変化させ るかを観察するには, 解糖系及び糖新生系の律速過程を不可逆的に触媒する各々の key enzyme 活性比を それぞれのステップについて検討するてとが最善であろう。一般て代謝の flux は律速醳素の最大活性より 遥が大であるとされる ${ }^{46}$ が，少なくとも醉素活性と metabolic flux はほぼ平行するので醉素活性比の刘 比より論して差支えない. Fig. 8 亿みる如く大量の「イ」投与によつて解糖系律速醳素活性 / 糖新生系律速 酵素活性比は G6Pase〜HK, GK のステップで明らかに非肥満群と肥満群に差を喼めるに反し，PEP-GK〜 PK ステップでは両群との間で差はみられない，即ち「イ」効果はラットの場合にはPEP-CK〜PK ステッ プの channeling にあると思われるが，当マウスではむしろ G6Pase〜GK, HK ステップの channeling に あると考えられる．肥満マウスのうち高血糖の甚しい例と比較的血糖值の低い例を 2 大別して，それぞれ同 様の活性比を検討するに前者では活性比はさらに低減し，後者では断頭時の活性比と殆んぞ異るとてろはな い，即ち肥満度とは無関係に糖尿病状態には軽重があり，且つその重症度は肝醉素の「イ」感受性に明確に 反映されている，比較的低い血糖值を示したマウスの糖尿病が将来さらに重症化する可能性は否定できない が, 年令的にみてその可能性は小さいと考えられるから, 著者の成績は明らかに肥満マウスの肥満要因と糖 尿病要因とは本質的に異つたものであるてとを示唆している。肥满を齋らす原因が淔ちに糖尿病を齋らすも のではないとするならば，肥満は単に「イ」抵抗性を来たす糖尿病の修飾因子にすぎないとも考えうる。肥 満と糖尿病が極めて高頻度に共存することは肥満マウスに限らず臨床的にもよく知られた事実であるが，代 謝学的な肥満要因と糖尿病要因の解離は自然発症糖尿病動物に於てもしばしば観察されるとてろである.

Chlouverakis らは BH 肥満マウスと同腹の非肥満マウスについてグルコース負荷を行ない比較検討し，負 荷量を体重と無関係に $100 \mathrm{mg}$ 亿一定にす机ば耐糖能には両者差を認めないが, 負荷量を体重に応じて $5 \mathrm{~g} / \mathrm{kg}$ に増量すれば, 肥満マウスの耐糖能曲線は明らかに diabetic となること, 静脈内糖負荷の場合には体重に 応じて $(\mathrm{lmg} / \mathrm{g} \cdot$ b.w $)$ 投与しても肥満マウスと非肥満マウスのK值には差異を生じないととを認めている.

さらに heterozygous の両親より生まれた生後 3 週のマウスの体脂肪・体液の体重比の検索から, 体重が有 意に大であるのみならず，体脂肪/体重比が明らかに大で，体液/体重比が有意に小さい群が汇別されるが， その血糖值には正常群と差のないてとを認め, 肥满が糖尿病に先行し肥満に基づく「イ」抵抗性が高血糖を 続発するものと結論している。彼らの glucose tolerance test に関する成績は肥満マウスと非肥满マウスの 脂肪組織の cellularity 亿差がないととを前提としているが，その点は明らかでない，さらに cellularityの 差いかんに拘らずグルコース負荷時の初期血糖上昇の差は主として肝に於ける糖処理機能の差によると解す べきであり，著者の認めた如き肥満マウスの肝解糖系䣼素の「イ」感受性低下が大きな問題となる筈である. 肥满マウスでは消化管よりの吸收速度が大であるとする報告 ${ }^{42} も$ 散見されるが，それのみで肥満マウスにみ られる強い糖忍容力低下は説明できないととは明らかである。 上述の論点から著者の肝醉素に関する成績が 糖永病の成因として無視し得ない factor であるととには疑いない，肝醳素の「イ」感受性減退が如何なる メカニズムに基づくかは不明であるが，Chlouverakis らの云う如く肥満が糖尿病に先行するものとすれば 
肥満をもたらす原因が肝酩素の「イ」感受性を低下せしめる可能性が生ずる。例えば肝内遊離脂酸量が増加 すれば, key glycolytic enzyme 活性は抑制せられ, key gluconeogenic enzyme 活性が元進するととは広 く認められているが(44)45), 脂肪負荷ラットの内臟全剔肝残存特殊標本に於いても又 glucocorticoid 前処置 ラット標本に於いても「イ」の肝醳素活性に及ぼす早期効果は明瞭に認められるし又肥満マウスで肝内脂酸 量乃至肝一の脂酸供給が有意に増加している証拠はなく ${ }^{43)}$, 肝内脂酸増加が「イ」感受性低下の主因とは考 え難い. 肝の glycolytic, gluconeogenic key enzymes はいずれも allosteric enzymes であり, 従つて種々 の nutrients を供給しつつ hormone の影響を観察することは至難である. 現在上記の「イ」の早期効果の 発現機序に就いては追及中である。

\section{$\mathrm{V}$ 結 語}

本研究は hyperinsulinism を伴う糖尿病の成因について自然発症肥満・高血糖マウスを用い実験的に追 求したものである. 即ち月令 4 ケ月及び 8 ケ月前後の肥満・高血糖マウスに肝残存内藏全剔手術を行ない門 脈内にグルコース及びインスリンを20分にわたり持続注入後, 肝糖新生・解糖系律速醳素活性を測定し, 同 腹の非肥満・正常マウスと比較検討した。

1、肥満・高血糖マウスの糖新生・解糖系律速醉素活性はいずれも刘照マウスの数倍高值を示すが老令化 と共佂正常化する.

2. 対照マウスの解糖系律速酻素活性は「イ」投与により速やかに有意の上昇を示すが，肥満・高血糖マ ウスでは有意の変化を認めない，糖新生系律速酻素活性は両群共に「イ」感受性を示さない.

3. 解糖系醉素活性の「イ」反応性と血糖值とは相関するが肥満度とは相関しない.

4. 糖新生系律速醉素活性とそれに対応する解糖系律速酵素活性比は「イ」投与後 glucose $一 \rightarrow$ glucose6-phosphate のステップで有意の変動を示し，「イ」早期効果の一次性の作用点であるととを示す.

5.上記の諸成績に基いて hyperinsulinemia を伴う糖尿病の成立には肝における「イ」依存機構の障害 が重要な因子と考觉られる.

稿を終るに臨み御校閲を睗わつた山田弘三教授, 終始指導, 助言を載いた坂本信夫講師に樑謝する。また 協力戴いた術者の宫脇洋隆博士, 糖尿病研究室の諸氏に心加謝意を表する。

本論文の要旨は第13回日本桾尿病学会総会（昭和45年）にて発表。

\section{文献}

1) 坂本信夫 : 糖尿病, $11: 289$ (1968).

2) 坂本信夫：糖尿满， $12: 237$ (1969).

宮脇洋隆 : 日内泌誌, $46: 928$ (1970).

4) 野村 了: 日内泌誌, $46: 454$ (1970).

Vinuela, E., Salas, M., and A. Sols : J. Biol. Chem., $238: 1175,3535$ (1963).

6) Underwood,

A.H., and E.A. Newsholme. : Biochem. J., 95 : 868 (1965).

7) Bücher, T., and G. Pfeiderer.

: Methods in Enzymology, Vol. 1, 1st ed. (1955) 435, Academic Press, New York.

8) Harper,

A.E. : Methoden der enzymatischen Analyse, 1st. ed. (1962) 744, Verlag Chemie, Weinheim.

Backer, E., and Schroender, E.A.R., Arch. Biophys. Biochem., $74: 326$ (1958)

10) Ballard, F.J., and R.W. Hanson : J. Biol. Chem., $242: 2746$, (1967).

11) Löhr, G.W., und H.D. Waller.: Methoden der enzymatischen Analyse, 1st ed. (1962) 788, Verlag Ghemie, Weinheim. 12）土田 勇：糖尿病， 9:67 (1966).

13) Sols, A., M. Salas, and E. Vinuela. : Adv. in Enzyme Reg., 2 : 177 (1964). 14) Weber, G. : ibid, $1: 1$ (1963). 15) Pitot, H.C., C. Peraino, N. Pries, and A.L. Kennan. : ibid $2: 237$ (1964). 16) Ricketts, H.T., R.A. Gherry, and L. Kirsteins. : Diabetes, $15: 880$ (1966). 17) Kipnis, D.M. : Pathogenesis of Diabetes Mellitus, ed. E. Gerasi and R. Luft (1969) 45, Almgvist \& Wiksell, Stockholm. 18) Antoni- 
ades, H.N. : Diabetes, $13: 230$ (1964).

and A Labhart. : J. Clin. Invest. $42: 1816$ (1963).
19) Froesch, E.R.,H. Bürgi, E.B. Ramseier, P. Bally,

20) Samaan, N.A., W.J. Dempster, R.

Fraser, N.W. Plaplease, and D. Stillman. : J. Endocrinol. $24: 263$ (1962). 21) VallanceOwen, J. : Diabetes, $13: 241$ (1964). $\quad$ 22) Galloway, J.A., Root, M.A., Ghance, R.E., Ratmacher, R.P., Ghalloner, D.R., and W.N. Shaw : Diabetes, 19 (Suppl. 1) : 341 (1970).

Fineberg, S.E., and T.J. Merimee. : Science, $167: 998$ (1970).

24) Lazarus, N.R., J.G. Penhos,

T. Tanese, L. Michaels., R. Gutman, and L. Recant. : J. Glin. Invest., 49 : 487 (1970).

Toomey, R.E., W.N. Shaw, L.R. Reid, and W.K. Young. : Diabetes, $19: 209$ (1970).

Poffenbarger, P.L., W.L. Ghick, R.L. Lavine, J.S. Soeldner, and J.H. Flewelling. : Diabetes, $20: 677$ (1971). 27) Magyar, I., D. Lehoczky, and I. Marton. : Lancet, ii : 79 (1963). Tamas, G., and M. Szögyi. : Diabetologia. $6: 649$ (1790).

29）馬場方平：日内泌誌, $46: 850$

(1970).

603 (1967).

(1970). $172: 821$ (1967).

30) Seidman, I., A.A. Horland, and G. W. W., A.E. Lambert, D. Vecchio, and A.E. Renold. : Diabetologia, $3: 230$ (1967). 35) Söling,

31) Willms, B., P. Ben-Ami, and H.D. Söling. : Horm. Metab. Res., 2 : 135

32) Gonet, A.E., A. Junod, and A.E. Renold. : Excerpta. med. Congress Series No. 33) Sneyd, J.G.T. : J. Endocrinol,, $28: 163$ (1964).

34) Stauffacher, H.D. : Diabetes Mellitus : ed I. Magyaru \& A. Beringer. II. (1971) 593, Verlag der Wiener. Med. Akademie, Wien. $\quad 36)$ Westman, S. : Diabetologia, $4: 141$ (1968). $\quad 37)$ Abraham, R.R., and A. Beloff-chain : Diabetes, $20: 522$ (1971). $\quad 38)$ Stauffacher, W., and A.E. Renold.: Amer. J. Physiol., $216: 98$ (1969). $\quad 39)$ Hales, G.N. : Essays in Biochemistry. $3: 73$ (1967).

40) Vester, J.W., and M.L. Reino. : Science $142: 590$ (1963).

41) Ghlouverakis, C., E.F. Dade, and R.A.L. Blatt : Metabolism $19: 687$ (1970).

42) Mayer, J., and C.Z. Yannoni. : Amer. J. Physiol., $185: 49$ (1956).

43) Abraham, R.R., E. Dade, J. Elliott, and D.A. Hems. : Diabetes, $20: 535$ (1971).

Biochem., $4: 364$ (1968). 44) Söling, H.D., B. Willms, D. Friedrichs, and J. Kleineke. : Europ. J. 107 (1965).

45) Struck, E., J. Ashmore, and O. Wieland : Biochem. Z., 343 :

46) Scrutton, M.G. : Ann. Rev. Biochem., $37: 249$ (1968). 